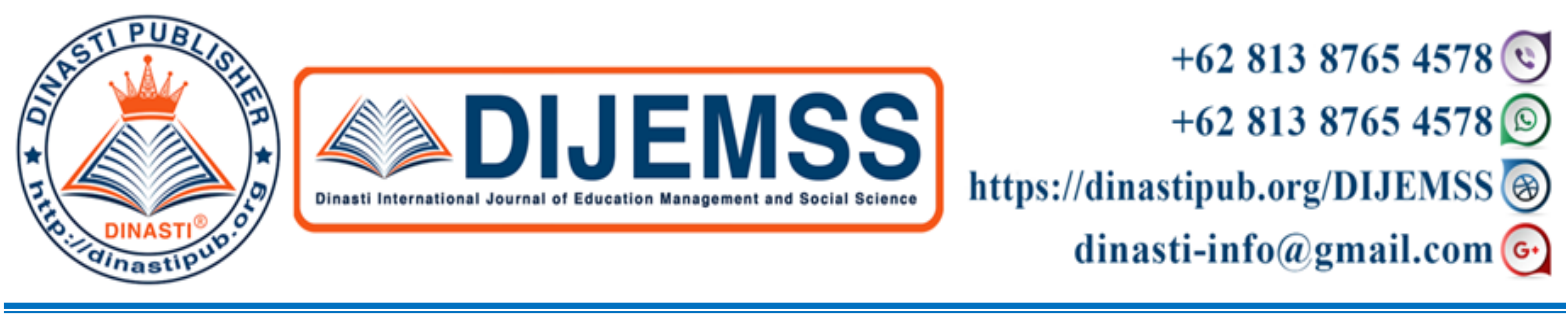

\title{
MODEL OF REJUVENATION OF OIL PALM PLANTATIONS BASED ON COMMUNITY EMPOWERMENT ON TRANSMIGRANT FARMERS' LAND
}

\section{Endang Solichin ${ }^{1,}$ Mardalena $^{2}$, Nugroho ${ }^{3}$}

1) Economic Education Study Program STKIP YPM, Merangin, Indonesia

${ }^{2)}$ Economic Education Study Program STKIP YPM, Merangin, Indonesia

${ }^{3)}$ Non Formal Education Study Program STKIP YPM, Merangin, Indonesia

\begin{tabular}{|c|c|}
\hline $\begin{array}{c}\text { ARTICLE INFORMATION } \\
\text { Received: } 26^{\text {th }} \text { June } 2020 \\
\text { Revised: } 25^{\text {th }} \text { July } 2020 \\
\text { Issued: } 22^{\text {th }} \text { August } 2020 \\
\text { Corresponding author: First Author } \\
\text { E-mail: } \\
\text { solend27@yahoo.com } \\
\text { mardalena@stkipypmbangko.ac.id } \\
\text { sarinahrina584@gmail.com }\end{array}$ & $\begin{array}{l}\text { Abstract: Empowerment of the weak economic } \\
\text { community is an effort to enable and empower the } \\
\text { community. transmigration is a model of population } \\
\text { distribution as well as an effort to improve the welfare } \\
\text { of the economically weak community in the } \\
\text { agricultural sector. The purpose of this study was to } \\
\text { examine the model of rejuvenation of oil palm } \\
\text { plantations based on community empowerment on oil } \\
\text { palm land owned by transmigrants in Pulau Tujuh } \\
\text { village, Mampun Village and Rasau Village, } \\
\text { Pamenang Barat District, Merangin District, Jambi } \\
\text { Province. The focus of this research is the model of } \\
\text { rejuvenation of community empowerment-based oil } \\
\text { palm plantations on oil palm farms belonging to } \\
\text { transmigrant farmers in Pulau Tujuh village, Mampun } \\
\text { Village and Rasau Village, West Pamenang District, } \\
\text { Merangin District, Jambi Province.The methods used } \\
\text { in this study were interviews, observations and } \\
\text { discussions with oil palm farmers transmigrants in the } \\
\text { village. The results of the study found a model for the } \\
\text { rejuvenation of oil palm plantations based on the } \\
\text { empowerment of migrant oil palm farmers by } \\
\text { combining three main forces, namely the Fund } \\
\text { Provider, Core People, Plasma and Government } \\
\text { companies, in the form of Four point Zero in Pulau } \\
\text { Tujuh Village, Mampun Village and Rasau Village } \\
\text { Pamenang District West Merangin district. } \\
\text { Keywords: Rejuvenation, Oil Palm, Empowerment, } \\
\text { Transmigrant. }\end{array}$ \\
\hline
\end{tabular}




\section{INTRODUCTION}

Oil palm is one of the plantation crops that has very high economic value. The area of oil palm plantations in Indonesia in 2018 was around 14.03 million hectares, of the 14.03 million hectares, 5 million hectares of oil palm plantations belonged to the people and the rest were owned by private plantation companies and state plantations. Indonesia is the largest palm oil producer in the world, followed by Malaysia and Thailand. The land of oil palm plantations in Jambi province is around 714,399 hectares, the total production is 1,794,874 tons, of which 714,399 hectares are 450,075 hectares or 63 percent are smallholders with a production of 998,234 tons [1].

In Jambi Province there are 63,000 hectares of oil palm land that are no longer productive, the average oil palm land owned by smallholders in the area has reached 25 years old, which is planted in the transmigration program in 1990 so it needs rejuvenation. The funds needed for rejuvenation are not less than Rp. 61.5 Million per hectare. Farmers have difficulty providing such a large amount of funds, therefore the government in this case the Palm Oil Plantation Fund Management Agency needs to provide access to funding for the cost of the rejuvenation.

The age of oil palm plants is one factor that is a consideration in the rejuvenation of oil palm plants. Old plant life is a consideration in rejuvenation because physiologically old plants ranging in age from 19 to 25 years have declining productivity, so that in terms of the economy, it no longer provides economic benefits. At the age of old plants the productivity of planting is low, on average 1 ton / ha / month, old plants generally have high trees so that when farmers will harvest difficulties, this greatly affects the high cost of production and results in inefficiencies [2].

This period of rejuvenation is a non-productive period, so that oil palm farmers do not have income, such conditions are exacerbated by the consumerism of the transmigrant farmers, when high productivity results in their high income generally the largest share of income is spent for shopping, the nature of consumerism very problematic when productivity is declining especially during rejuvenation where they have no income for living expenses. When income rises, consumption rises proportionally and when income decreases disproportionately, so this affects their behavior, dissaving will occur in these conditions, for those who have savings they will withdraw their savings, for those who have their goods will sell it and for those who do not have wealth, are prone to commit criminal acts.

There are two things that are at the center of attention during the rejuvenation of the oil palm land, namely oil palm transmigrants as actors and rejuvenation of the oil palm land itself, so that there are two main problems in this rejuvenation period, namely the income of oil palm farmers and rejuvenation. in this case is how to secure the income of oil palm farmers' transmigrants during rejuvenation and rejuvenation that empowers farmers. The main problem in this study is the rejuvenation model of how farmers keep their income for survival and rejuvenation can work well, it is necessary to design an appropriate rejuvenation model to overcome the problem of rejuvenation on oil palm plantations belonging to transmigrant farmers in the three villages. 


\section{LITERATURE REVIEW}

The concept of community empowerment contains an understanding of development that relies on society, the community is the perpetrator of development and at the same time the goal of development [3]. Relying on society means that society is the object and subject of development, in the concept of empowering weak economic communities, who are marginalized, do not have assets and access to resources, such as transmigrants who because of limited resources at their place of origin, have to move away from the village where they live origin.[4] One of the important activities in the management of oil palm land is a rejuvenation program that must be prepared properly, especially for smallholder farmers' land because it is related to the amount of funding, around Rp. 61.5 Million per hectare.

There are four types of rejuvenation systems, namely simultaneous uprooted systems, underplanting systems, gradual systems and intercropping, the four systems each have advantages and disadvantages, in a simultaneous uprooted system, land preparation and tillage can be carried out more intensively and provide ideal soil conditions for the growth of oil palm plants, but this system can cause loss of income because the production and sale of fresh fruit is completely cut off. The underplanting system still provides an opportunity for farmers to earn income from old plants that have not been cut down, but this system can cause disruption to the growth of young plants [5].

In a gradual replanting system farmers can still obtain income from old plants that have not been rejuvenated, but this system is less effective when applied to small land, such as transmigrant farmers' oil palm land. The intercropping system provides alternative income through intercropping, undisturbed young plant growth and intercropping residues are expected to be an organic source and help supply nutrients to young plants, but this system requires intensive crop management and of course requires the right marketing techniques and chains for production intercropping can be absorbed by the market.[6]

Rejuvenation activities on transmigrant farmers 'oil palm land can cause their income to cease, therefore the rejuvenation of oil palm land for transmigrant farmers must consider the sustainability of the farmers' income. In addition, the rejuvenation system of oil palm land owned by trasmigran farmers must also consider cost efficiency. The rejuvenation system that is considered to be in accordance with this model is a simultaneous uprooted system, because it is done in bulk it will be more efficient.

\section{RESEARCH METHODS}

The study was carried out in three villages in the West Pamenang sub-district of Merangin, Jambi Province, Indonesia. The three villages are Pulau Tujuh village, Mampun Baru village and Rasau village. This research was carried out on oil palm transmigrants as many as 29 farmers in the village.

The choice of location is based on the consideration that the oil palm plantations are nearing their economic age and that most of the people in this village depend their livelihood on oil palm plantations. This research was conducted in March 2018 until September 2018. The data taken consists of primary data and secondary data. Primary data in the form of farmer profile, garden profile, garden performance, and income level. Secondary data in the form of the condition of the research area, plantation area, oil palm production, prices of Fresh Fruit Bunches (FFB), and so forth. Primary data is obtained through direct interviews with farmers, discussions with and direct observation in the field. 


\section{Empirical data and analysis}

Based on the results of interviews, observations and discussions with oil palm transmigrants in Pulau Tujuh Village, Mampun Baru Village and Rasau Village, West Pamenang District, Merangin District, it was revealed that in the rejuvenation process there were four elements that played a major role in the success of community-based rejuvenation, the four elements are elements of farmers or farmer groups (plasma), funders or banks / Palm Oil Plantation Fund Management Bodies, Company (core) and the government as a regulator. The first element, farmers or farmer groups (plasma) as targets in empowerment must be institutionalized in the form of farmer groups, so that their behavior from the farmers is patterned in a model, this is very necessary to reduce or control the behavior of farmers so that the program can run as it should be. From the aspect of the farmer element that needs attention is how farmers can have income during this rejuvenation period for their survival. The second element, the funder is an institution that provides funding for rejuvenation financing such as the Palm Oil Plantation Fund Management Agency or banking, by giving a grace period during the rejuvenation period. The third element, the Core Company that manages rejuvenation in collaboration with farmer groups. The fourth element, the government that makes regulations to ensure this empowerment model runs as it should.

\section{FINDINGS AND DISCUSSION}

The results of the study showed that there were three stakeholders and elements of the government as regulators, the three elements being farmers belonging to a farmer group (plasma) as a target in empowering weak economic communities, the second companies (core) and the third being funding institutions in the form of banking or the Palm Oil Plantation Fund Management Agency as well as policy holders who compose regulators, namely the government. First, The farmer group enters into a cooperation contract in the provision of funds for rejuvenation purposes with the funders, can be banking or other institutions. Both parties determine the amount of funds needed and the grace period.

Second, The farmer group entered into a cooperation contract with the company to manage the rejuvenation program with the amount of the cost. Third, Companies in managing the rejuvenation of oil palm land, using farmers who are members of farmer groups to work on the rejuvenation program as a company workforce.

Fourth, The company integrates the management of resources in the form of capital goods, the use of large machinery to process land, and farmers provide their workforce.

The model can be explained as follos :

1. The government made a policy outlined in the regulation on the rejuvenation of oil palm land which involved three parties, namely farmers, nucleus companies and banks / Palm Oil Plantation Fund Management Agency,

2. Based on this government policy, farmers (Plasma) enter into a contract of cooperation with the company (core), the main problem in the collaboration is that farmers hand over the management of farmers' oil palm land rejuvenation to companies and companies using the farmers in rejuvenation as workers paid by the company .

3. Farmers submit funding or credit for rejuvenation fees to banks or the Palm Oil Plantation Fund Management Agency, which is then handed over to the company. This model of oil palm plantation rejuvenation will benefit all parties, such as: 
3.1 Managing the rejuvenation of oil palm plantations in bulk will be more efficient in terms of financing, using technology or heavy equipment together.

3.2 The company will guarantee the supply of raw materials so that the sustainability of production will not be hampered.

3.3 Transmigrant farmers will get income for their living expenses from their income as workers or laborers in the construction of their oil palm land.

\section{CONCLUSION AND SUGGESTION}

Rejuvenation of oil palm land belonging to transmigrant farmers in Pulau Tujuh Village, Mampun Village and Rasau Village, is a must because it has reached the age of plants that have no economic value. The limitation of the resources owned by farmers in the village is a reality, so it is necessary to find a model that can be applied by considering the empowerment of weak economic communities, namely by empowering resources owned by stakeholders, both companies, transmigrant farmers, funding and government providers in a four in one model

\section{REFERENCE}

Direktorat Jenderal Perkebunan, Statistik Perkebunan Indonesia 2015-2017 Kelapa Sawit, Sekretariat Jenderal Perkebunan Direktorat Jenderal Perkebunan, Kementerian Pertanian. Azman Ismail and Mohd Noor Mamat, (2002), The Optimal Age of Oil Palm Replanting, Oil Palm Industry Economic Journal, Volume 2

Kartasasmita, Ginanjar, (1997), Pemberdayaan Masyarakat : Konsep Pembangunan yang Berakar Pada Masyarakat, Surabaya

KH, Ramadhan, Hamid Jabbar, Riffiq Ahmad, (1993), Harapan dan Tantangan Departemen Transmigrasi. Departemen Transmigrasi RI, Jakarta

Wisnu Hari Wibowo and Ahmad Junaedi, (2017), Replanting of Palm Oil in Seruyan Estate, Minamas Plantation Group. Seruan Central of Borneo, Bul. Agrohorti 5 (1) : 107-116 (2017)

Idris Omar, Azman Ismail and Chang Lin Chog, (2001), Improving Productivity : The Replanting Imperative, Oil Palm Industry Economic Journal, Volume 1

Heeren, Hj, (2010), Transmigrate in Indonesia. Gramedia : Jakarta

Hikmat Harry, (2010), Strategi Pemberdayaan Masyarakat, Humaniora Utama Press : Bandung 